A N N A L ES

UNIVERSITATIS MARIAE CURIE-SKŁODOWSKA

LUBLIN - POLONIA

VOL. LXVI, 1

SECTIO G

2019

Uniwersytet Marii Curie-Skłodowskiej w Lublinie

PAWEŁ LESIŃSKI

pawel.lesinski@umcs.pl

ORCID: 0000-0001-6522-3625

\title{
O racjonalności państwa prawnego w myśli Roberta von Mohla ${ }^{1}$
}

The Rationality of the State of Law Idea in the Robert von Mohl's Thought

\section{WPROWADZENIE}

Tezą i głównym założeniem badawczym niniejszego artykułu jest wykazanie, iż pojęcie oraz zasady, na jakich bazowała idea państwa prawnego w nauce Roberta von Mohla, opierają się na racjonalnych regułach wynikających z doświadczenia życiowego i gwarantujących efektywność działania. Aby zrealizować powyższy cel, podjęto próbę zrekonstruowania pojęcia państwa i władzy racjonalnej, wykorzystując m.in. dorobek Maxa Webera. Następnie omówiono definicję państwa oraz poszczególne jego rodzaje, które występowały w nauce von Mohla. Ostateczne udowodnienie tezy o racjonalności Mohlowskiego konceptu państwa prawnego zostało dokonane poprzez jego analizę w kontekście pozostałych rodzajów państw oraz omówienie zasad, według których Rechtsstaat powinno wspierać obywateli w realizacji ich życiowych dążeń.

1 Chcąc odnotować obecność koncepcji von Mohla na gruncie nauki polskiej, należy wskazać na jedyne wydane w języku polskim dzieło uczonego, czyli Encyklopedię umiejętności politycznych (Warszawa 2003), której współczesną wersję opracował i opatrzył wstępem Adam Bosiacki. Więcej o von Mohlu i jego poglądach zob. L. Dubel, Robert von Mohl, [w:] idem, Historia doktryn politycznych i prawnych do schytku XX wieku, Warszawa 2012, s. 353-357; B. Sobolewska, M. Sobolewski, Myśl polityczna XIX i XX wieku. Liberalizm, Warszawa 1978, s. 466. Na temat koncepcji państwa prawnego w Niemczech zob. A. Bosiacki, Egalitaryzm a elitaryzm w klasycznej koncepcji państwa prawnego w Niemczech XIX wieku, [w:] Księga życia i twórczości. Księga Pamiatkowa dedykowana Profesorowi Romanowi A. Tokarczykowi, t. 5: Prawo, red. Z. Władek, J. Stelmasiak, W. Gogłoza, K. Kukuryk, Lublin 2013. 


\section{CECHY PAŃSTWA RACJONALNEGO}

Głównym celem opracowania, jak wskazano wyżej, jest wykazanie racjonalności pojmowania państwa prawnego w myśli von Mohla. Aby uniknąć pewnej jednostronności wywodu, a także dla ukazania swoistych „,wzorców porównawczych", warto na początku odpowiedzieć na pytanie, jakie ogólne cechy powinny charakteryzować racjonalne państwo działające w oparciu o racjonalną władzę.

Słowo „racjonalność” czy „racjonalny” wywodzi się z języka łacińskiego, gdzie rationalis oznacza 'rozsądny', a ratio to 'rozum'. Według definicji Władysława Kopalińskiego ratio (,racjonalność”) jest czymś rozumnym, opartym na zasadach poprawnego myślenia i skutecznego działania, ale jest to również coś uzasadnionego logicznie i rozumowo ${ }^{2}$. Racjonalne jest takie działanie, które można uznać zarówno za sensowne i właściwe, jak i potrzebne ze względu na powszechnie uznany cel, na jaki jest nakierowane ${ }^{3}$. Z kolei niemiecki socjolog prawa Thomas Raiser łączy racjonalność z greckim Logos, intelektem, rozsądkiem (Vernunft), tzw. sensownością (Sinnhaftigkeit) myślenia i działania oraz dokonywaniem refleksji i rozsądnym argumentowaniem ${ }^{4}$. Natomiast Wolfgang J. Mommsen racjonalną władzę określa jako formalno-prawny system ustrojowy oparty na racjonalności celów5.

Niebagatelne zasługi dla zdefiniowania racjonalnego działania państwa trzeba przypisać też M. Weberowi, niemieckiemu klasykowi socjologii ${ }^{6}$. Wyróżnił on cztery idealne typy działania społecznego: tradycjonalne i afektywne (można je określić jako nieracjonalne) oraz oparte na rozumie, czyli celowo racjonalne i wartościowo racjonalne ${ }^{7}$. Działania nieracjonalne bazują u Webera na emocjach albo tradycji (np. wywodzą się z przyzwyczajeń). Z kolei działania racjonalne albo mogą być nastawione na osiągnięcie określonego celu (zweckrational), albo

2 W. Kopaliński, Stownik wyrazów obcych i obcojęzycznych z almanachem, Warszawa 2007, s. 480. Więcej o pojęciu racjonalności: K. Wielecki, Władza i podmiotowość, „Zeszyty Naukowe Wyższej Szkoły Bankowej w Poznaniu" 2013, nr 4, s. 159-160.

3 S. Blackburn, Oksfordzki stownik filozoficzny, Warszawa 2004, s. 337.

4 T. Raiser, Max Weber und die Rationalität des Rechts, „Juristen Zeitung“ 2008, Nr. 18, s. 858 ,

5 S. Breuer, Rationale Herrschaft. Zu einer Kategorie Max Webers, „Politische Vierteljahrschrift“ 1990, Bd. 31, Nr. 1, s. 5.

6 Więcej o teorii polityki i władzy u Webera zob. D. Beetham, Max Weber and the Theory of Modern Politics, Cambridge 1985.

7 M. Weber, Gospodarka i społeczeństwo. Zarys socjologii rozumiejacej, Warszawa 2002, s. 17-19. Por. K. Wielecki, op. cit., s. 160. O poszczególnych typach działań u Webera zob. A. Swidler, The Concept of Rationality in the Work of Max Weber, "Sociological Inquiry" 1973, Vol. 43(1), s. 38-42; D.N. Levine, Rationality and Freedom: Weber and Beyond, "Sociological Inquiry" 1981, Vol. 51(1), s. 11. 
mogą być racjonalnymi ze względu na wartości, które im przyświecają (wertrational $)^{8}$. Działanie celowo racjonalne cechuje nastawienie na realizację określonego celu oraz rozważanie wszelkich dostępnych do jego realizacji środków9

Odnosząc się do typów prawomocnego panowania (władzy), Weber wyróżnił: panowanie racjonalne (nazywane również legalnym), opierające się na prawie i warunkowanym przez nie porządku; panowanie tradycjonalne, którego podstawą jest wiara w panującą tradycję; panowanie charyzmatyczne, bazujące na wierze $\mathrm{w}$ panowanie nieprzeciętnej jednostki ${ }^{10}$. Władza legalna (nazywana też władzą legalno-racjonalną) ${ }^{11}$, w przeciwieństwie do władzy tradycjonalnej czy charyzmatycznej, jest oparta na prawie ${ }^{12}$. Dominuje w niej przekonanie o nadrzędności prawa ustanowionego dla osiągania celów wspólnotowych ${ }^{13}$. W panowaniu legalnym obowiązują zracjonalizowane procedury, rządzi prawo, a legitymacją ustanowionego porządku są wartości celowo racjonalne lub wartościowo racjonalne ${ }^{14}$. Jak słusznie stwierdził Krzysztof Wielecki, racjonalności celowej, właściwej dla kapitalizmu i gospodarki industrialnej, u Webera mają odpowiadać legalny typ panowania oraz nowoczesna biurokracja ${ }^{15}$.

Szczególną rolę Weber przypisuje administracji państwa, gdyż to właśnie „panowanie za pośrednictwem biurokratycznego sztabu administracyjnego”16 miało być najczystszym typem panowania legalnego. W państwie legalno-racjonalnym, oprócz oparcia go na prawie, musi więc funkcjonować administracja oraz specjalny system urzędniczy, czyli biurokracja. Jej działanie Weber opisał jako „racjonalną troskę o wskazywane przez porządki związku interesy, w granicach wyznaczanych przez reguły prawne, i zgodną z ogólnymi zasadami, aprobowanymi lub przynajmniej nie dezaprobowanymi, przez porządki związku"17. Biurokracja (rozumiana jako zjawisko pozytywne), zajmująca jedno z centralnych miejsc

8 T. Raiser, op. cit., s. 854. Por. Z. Drozdowicz, O racjonalności w religii i w religijności (raz jeszcze), Poznań 2010, s. 34-35.

9 M. Weber, op. cit., s. 18-19. O typie działania racjonalnego u Webera zob. P. Polaczuk, O racjonalności działania w ujęciu Maksa Webera, „Studia Warmińskie” 2011, t. 48, s. 9-20.

10 M. Weber, op. cit., s. 160. O różnych typach panowania u Webera zob. M. Augustyniak, Max Weber o władzy i odpowiedzialności w polityce, „Studia Prawnoustrojowe” 2010, nr 11, s. 4350. Por. S. Mazur, Historia administracji publicznej, [w:] Administracja publiczna, red. J. Hausner, Warszawa 2003, s. 54.

11 H. Constas, Max Weber's Two Conceptions of Bureaucracy, "American Journal of Sociology" 1958, Vol. 63(4), s. 401.

12 T. Raiser, op. cit., s. 854.

13 P.M. Blau, Critical Remarks on Weber's Theory of Authority, "The American Political Science Review" 1963, Vol. 57(2), s. 308.

${ }_{14}$ M. Augustyniak, op. cit., s. 48.

15 K. Wielecki, op. cit., s. 160.

16 M. Weber, op. cit., s. 164.

17 Cyt. za: M. Augustyniak, op. cit., s. 49. 
w Weberowskiej analizie władzy legalnej ${ }^{18}$, może być więc nazwana uosobieniem instytucjonalnym władzy legalno-racjonalnej ${ }^{19}$.

Podsumowując tę część rozważań, warto pokusić się o stwierdzenie, że państwo chcące realizować swą władzę w sposób racjonalny powinno kierować się logiką i racjonalnością celów, jakie sobie stawia. Do cech państwa racjonalnego należy zaliczyć uznanie przepisów prawa za źródło wszelkich działań władczych, jak również posiadanie instrumentów do realizowania obranych przez siebie celów w postaci aparatu administracyjno-biurokratycznego.

\section{POJĘCIE PAŃSTWA}

Zanim zostanie dowiedziona teza, iż państwo prawne w myśli von Mohla spełnia warunki do bycia uznanym za strukturę racjonalną, należy przynajmniej w sposób skrótowy poddać analizie samą definicję państwa, jaka występuje i ewoluuje w myśli uczonego przez cały okres jego pracy naukowej. Jest to o tyle istotne, że już w ogólnej definicji państwa widać zarys jego „racjonalno-subsydiarnego sznytu”, który objawi się z całą mocą przy omawianiu Mohlowskiego Rechtsstaat.

Pierwsza definicja pojęcia „państwo” pojawia się u niemieckiego liberała w jednym z jego najwcześniejszych dzieł, czyli w Prawie Państwowym Królestwa Wirtembergii. W pierwszym wydaniu tej publikacji von Mohl definiuje państwo jako „uosobienie instytucji odnoszących się do uporządkowanego, zespolonego życia określonej zbiorowości (narodu) oraz znajdujących się na określonym terytorium" ${ }^{20}$. Po lekturze powyższej definicji nasuwa się stwierdzenie, iż jest ona dość ogólnikowa i mało rozbudowana. Uczony we wczesnych latach swej działalności oczywiście zauważa państwo i dostrzega, że jest to suma określonych „instytucji” (Anstalten) ${ }^{21}$. Rozumie je jako organizację porządkującą życie ludzi zgromadzonych na ograniczonym terytorium, lecz nie wypełnia swej definicji innymi, materialnymi aspektami działalności państwa.

Podobna definicja pojawia się w następnym dziele, czyli w Nauce o policji zgodnie z zasadami prawa państwowego, w którym von Mohl pisze o państwie

18 P.M. Blau, op. cit., s. 309.

19 O problemie biurokracji u Webera zob. H. Constas, op. cit., s. 400-409; R.A. Hilbert, Bureaucracy as Belief, Rationalization as Repair: Max Weber in a Post-Functionalist Age, "Sociological Theory" 1987, Vol. 5(1), s. 70-86.

20 R. von Mohl, Das Staatsrecht des Königreiches Württemberg, Erster Theil, Tübingen 1829, s. 3.

21 Należy zauważyć, iż von Mohl był przekonany, że to właśnie słowa ,instytucja”, ,urządzenie" (niem. Einrichtung, Anstalt) najlepiej opisują wielką różnorodność części składowych państwa. Sprzeciwiał się używaniu słów „ustawy” czy „,normy prawne”, które uważał, co prawda, za części składowe organizmu państwowego, lecz niebędące nimi w sposób wyłączny. Zob. idem, Encyklopädie der Staatswissenschaften, Zweite Auflage, Tübingen 1872, s. 72. 
jako o „porządku wspólnego życia narodu na określonym terenie”22. Natomiast w drugim wydaniu Nauki o policji z 1844 r., nieco rozwijając poprzednią definicję, nazywa państwo „porządkiem wspólnego życia narodu, na określonym terytorium i pod najwyższą władzą" ${ }^{23}$. Najbardziej rozbudowana (również pod względem materialnym) definicja państwa pojawia się dopiero w Encyklopedii umiejętności politycznych. W drugim wydaniu tej księgi, opublikowanym u schyłku życia uczonego, von Mohl postrzega państwo jako:

[...] trwały, jednolity organizm tych instytucji, które prowadzone poprzez zbiorową wolę, jak i utrzymywane oraz realizowane poprzez zbiorową siłę, mają za zadanie wspierać odpowiednie, dozwolone cele życiowe, określonego i terytorialnie ograniczonego narodu, od jednostki aż po społeczeństwo, jeżeli przy użyciu własnych sił nie są one w stanie osiągnąć tych celów, a cele te mieszczą się w zakresie zbiorowych potrzeb ${ }^{24}$.

Nie jest celem niniejszego artykułu omawianie poszczególnych elementów powyższej, najbardziej rozbudowanej w nauce liberalnego Niemca, definicji państwa. Warto jednak stwierdzić, iż jednym z centralnych punktów wyżej przedstawionego pojmowania państwa jest jego szczególna rola w życiu obywateli. Zadaniem państwa miało być bowiem wspieranie celów życiowych przyświecających określonym jednostkom. O racjonalności ogólnej definicji państwa u von Mohla świadczy to, iż nie miało ono działać w sposób odgórny i bezrefleksyjny. Powinna je cechować subsydiarność, czyli wspieranie jednostek wtedy, gdy same nie były w stanie osiągnąć określonych, zaakceptowanych przez wspólnotę celów ${ }^{25}$.

\section{NAUKA O CELU I GATUNKACH PAŃSTW}

Według von Mohla cel państwa zawsze jest determinowany przez tzw. cele życiowe, jakie przyświecają jego mieszkańcom. Z uwagi na to, że „zmysłowo-racjonalna" natura ludzka jest tak wielowątkowa i bogata w różnych czasach i okolicznościach, różnym narodom - w zależności od stopnia ich rozwoju cywilizacyj-

22 Idem, Die Polizeiwissenschaft nach den Grundsätzen des Rechtsstaates, Erster Band, Tübingen 1832, s. 5 .

${ }^{23}$ Idem, Die Polizeiwissenschaft nach den Grundsätzen des Rechtsstaates, Erster Band, Zweite Auflage, Tübingen 1844, s. 4-5. Warto podkreślić, iż mówiąc o powstawaniu państwa, von Mohl w pewnym sensie nawiązuje do Arystotelesowskiego homo politicus, gdyż mówi o człowieku jako „zwierzęciu państwowym”, szukającym w państwie uporządkowania swojego życia. Zob. idem, Die Geschichte und Literatur der Staatswissenschaften in Monographieen dargestellt, Erster Band, Erlangen 1855, s. 91 . O społecznej naturze człowieka przekonany był również św. Tomasz z Akwinu. Zob. M. Łuszczyńska, Ubi ratio, ibi ius. Doktryna prawna Świętego Tomasza z Akwinu, Lublin 2013, s. 236-241.

24 R. von Mohl, Encyklopädie..., s. 72.

25 Por. J. Burska-Cieślak, Geneza pojęcia socjalnego państwa prawnego w doktrynie niemieckiej, [w:] Państwo - ustrój - konstytucja. Studia, red. L. Antonowicz, Lublin 1991, s. 28. 
nego - przyświecają różne cele ${ }^{26}$. Takie podejście determinuje pogląd, iż nie jest możliwe wskazanie takiego, a nie innego ogólnego celu państwa, właściwego dla każdego narodu, w każdym momencie jego historii ${ }^{27}$.

Oparcie się na racjonalnym doświadczeniu pokazuje, iż każdy lud wytwarza pewien specyficzny „,zbiorowy pogląd na życie” (Gesamt Lebensansicht), który determinuje cele, jakie chce osiągać większość jednostek, a tym samym społeczeństwo ${ }^{28}$. Zadaniem państwa jest natomiast dotrzymywanie kroku zmianom zachodzącym w poglądzie określonego narodu na to, jakie cele życiowe w nim dominują ${ }^{29}$. Von Mohl podkreśla: ,[...] psychologiczny charakter narodu jest (przynajmniej na dłuższą metę) identyczny z politycznym charakterem jego państwa: przyjęty przezeń cel ludzkiego życia jest również celem państwa" ${ }^{30}$ - między celem państwa a celami jego ludności nie może być więc sprzeczności ${ }^{31}$.

Skoro ludzka natura jest tak wielowątkowa, skoro narody oraz społeczeństwa - w zależności od poziomu swego rozwoju - podążają za różnymi celami ${ }^{32}$, to także państwo, przejmujące swój charakter polityczny od narodu, może przybierać różne formy i gatunki. Według von Mohla nie sposób wyróżnić wszystkie możliwe gatunki państw wynikające z celów i natury ludzkiej egzystencji ${ }^{33}$. Tyle będzie różnych gatunków państw oraz ich celów, jak wiele będzie zadań i celów życiowych określonych narodów ${ }^{34}$. Racjonalne doświadczenie pokazuje, że jedne narody za zasadę swego życia przyjmują religię, traktując życie doczesne tylko jako przygotowanie do życia wiecznego, inne zaś skupiają się jedynie na sprawach doczesnych i przyjemnościach ${ }^{35}$.

26 R. von Mohl, Die Polizeiwissenschaft nach den Grundsätzen des Rechtsstaates, Erster Band, Tübingen 1832, s. 4.

27 Idem, Encyklopädie..., s.74. Por. E. Angermann, Robert von Mohl 1799-1875. Leben und Werk eines altliberalen Staatsgelehrten, Neuwied 1962, s. 119-120. O poszczególnych gatunkach państw u von Mohla zob. Z.A. Maciąg, Kształtowanie zasad państwa demokratycznego, prawnego i socjalnego w Niemczech (do 1949 r.), Białystok 1998, s. 90-91; H. Schmitz, Die Staatsauffassung Robert von Mohls unter Berücksichtigung der verfassungs-geschichtlichen Entwicklung und des positivistischen Staatsdenkens, Köln 1965, s. 47-49.

28 R. von Mohl, Die Polizeiwissenschaft nach den Grundsätzen des Rechtsstaates, Erster Band, Zweite Auflage, Tübingen 1844, s. 7.

29 Idem, Encyklopädie..., s. 73.

30 Idem, Das Staatsrecht des Königreiches Württemberg, Erster Theil, s. 4.

31 Idem, Die Polizeiwissenschaft nach den Grundsätzen des Rechtsstaates, Erster Band, Tübingen 1832, s. 5 .

32 Ibidem, s. 3.

33 Idem, Das Staatsrecht des Königreiches Württemberg, Erster Theil, s. 6.

34 Idem, Die Polizeiwissenschaft nach den Grundsätzen des Rechtsstaates, Erster Band, Tübingen 1866, s. 4.

35 Idem, Die Polizeiwissenschaft nach den Grundsätzen des Rechtsstaates, Erster Band, Tübingen 1832 , s. $3-4$. 
Kierując się doświadczeniem życiowym, można jednak wskazać pewną grupę gatunków państw, które najczęściej występują w rzeczywistości historycznej ${ }^{36}$. Ich występowanie było determinowane stopniem rozwoju i racjonalności ludów, które je zamieszkiwały ${ }^{37}$. W drugim wydaniu Encyklopedii umiejętności politycznych von Mohl wymienia: państwo patriarchalne (Patriarchalische Staat), państwo teokratyczne (Theokratie), władztwo (państwo) patrymonialne (Patrimonial Herrschaft), państwo klasyczne (Klassiche Staat), państwo despotyczne (Despotie) oraz wreszcie państwo prawne (Rechtsstaat) ${ }^{38}$.

Państwo patriarchalne opierało się na zasadzie życia plemiennego. Poglądy i cele życiowe ludu zorganizowanego w takim państwie nie były wysoko rozwinięte, ich podstawę stanowiło podporządkowanie władcy plemiennemu („ojcu plemienia") $)^{39}$. Z kolei państwo teokratyczne bazowało na poglądzie, iż życie ludzkie na Ziemi powinno być postrzegane przez pryzmat religii ${ }^{40}$. Egzystencja doczesna była w tym państwie tylko procesem przygotowawczym do życia wiecznego. Wszystkie instytucje państwa miały charakter wyznaniowy, a jego działalność nie ograniczała się tylko do prawa, lecz również obejmowała strzeżenie moralności oraz przede wszystkim kontrolę kwestii religijnych. Von Mohl zwraca uwagę na fakt, iż państwo teokratyczne może być państwem najbardziej stabilnym (dopóki lud ma silną wiarę w religię będącą podstawą państwa). Z drugiej strony teokracja opiera się jednak nie tylko na nieracjonalnej „,iemności rozumu”, lecz także na nietolerancji wobec innych wyznań oraz jednostronności rozwoju jednostek ${ }^{41}$.

Gatunku państwa patrymonialnego również nie można nazwać racjonalnym, gdyż opierał się na „zmysłowo-dziecinnym poglądzie na życie" ${ }^{\text {"22 }}$. Państwo patrymonialne bazowało albo na stosunkach pokrewieństwa, albo na stosunkach majątkowych, przez co u von Mohla występuje jako jedno wielkie ,prywatne stowarzyszenie". Zasady obowiązujące w państwie były wywodzone zarówno z pra-

36 Idem, Das Staatsrecht des Königreiches Württemberg, Erster Theil, s. 7.

37 O gatunkach państw w nauce von Mohla zob. J. Nowacki, Państwo prawne w typologii państw Roberta von Mohla, [w:] Przybliżanie przeszłości. Ksiega pamiatkowa ofiarowana Profesorowi Czesławowi Głombikowi z okazji czterdziestolecia pracy nauczycielskiej, red. J. Bańka, Katowice 1998, s. 123-125.

38 R. von Mohl, Die Polizeiwissenschaft nach den Grundsätzen des Rechtsstaates, Erster Band, Tübingen 1866, s. 4. Warto również zauważyć, iż naukę von Mohla o gatunkach państw uzupełnia podział tychże na poszczególne „formy” (Arten). Każdy „gatunek państwa” (Staatsgattung) zyskuje zatem u uczonego kilka „form” (Arten der Staats-Gattungen), których obecność wynika m.in. z doświadczenia historycznego. Więcej: idem, Das Staatsrecht des Königreiches Württemberg, Erster Theil, s. 12; idem, Encyklopädie..., s. 103-104.

39 Ibidem, s. 104.

40 Idem, Das Staatsrecht des Königreiches Württemberg, Erster Theil, s. 7. Więcej: idem, Encyklopädie..., s. 104-105.

${ }^{41}$ Idem, Das Staatsrecht des Königreiches Württemberg, Erster Theil, s. 8-10.

42 Ibidem, s. 7. Więcej: idem, Encyklopädie..., s. 105. 
wa, jak i obyczaju i tradycji ${ }^{43}$. Z państwa patrymonialnego, u którego podstaw znajdowały się stosunki materialne, wykształca się państwo feudalne ${ }^{44}$. Celem państwa klasycznego, właściwego dla antycznych Rzymian i Greków, miało być jak najpełniejsze połączenie wspólnego życia wszystkich obywateli ${ }^{45}$. Natomiast państwo despotyczne opierało się na władzy silniejszego i służyło osiąganiu jego osobistych celów. Podstawami wszystkich działań i procesów w państwie despotycznym (oprócz stosunku siły) były obawa i strach. Nie mogło być więc mowy o podążaniu przez ludność despotii za jakimiś wyższymi celami ${ }^{46}$.

\section{PAŃSTWO PRAWNE JAKO BYT RACJONALNY ${ }^{47}$}

W momencie, gdy określony naród osiąga odpowiednio wysoki poziom rozwoju (czy też staje się wystarczająco racjonalny), organizuje on swą wspólnotę według zasad państwa prawnego (Rechtsstaat). Przez wielu ówczesnych niemieckich liberalnych uczonych, takich jak von Mohl czy Carl Theodor Welcker, Rechtsstaat uznawane było za jedną z najbardziej rozwiniętych i „,nowoczesnych” form ustrojowych ${ }^{48}$. To właśnie ten typ państwa był oparty na podstawie racjonalnej, na ,jasnym i wyliczonym, rozumnym poglądzie"49 (podobnie jak typ wła-

${ }^{43}$ Idem, Das Staatsrecht des Königreiches Württemberg, Erster Theil, s. 7. Warto wspomnieć o analizie państwa patrymonialnego w nauce konserwatywnego szwajcarskiego myśliciela Carla Ludwiga von Hallera. Zob. C.L. von Haller, Restauration der Staatswissenschaft oder Theorie des natürlich-geselligen Zustands, der Chimäre des künstlich-bürgerlichen entgegengesetzt, $1 \mathrm{Bd}$. , Winterthur 1820, s. 463; K. von Beyme, Geschichte der politischen Theorien in Deutschland 13002000, Wiesbaden 2009, s. 248-251.

44 R. von Mohl, Das Staatsrecht des Königreiches Württemberg, Erster Theil, s. 14. Więcej o państwie patrymonialnym opartym na rodzinie oraz o państwie patrymonialnym opartym na stosunkach majątkowych zob. ibidem, s. 12-14.

45 Idem, Encyklopädie..., s. 104-105.

46 Idem, Das Staatsrecht des Königreiches Württemberg, Erster Theil, s. 9.

47 O rozwoju pojęcia Rechtsstaat w nauce niemieckiej zob. K.H.F. Dyson, The State Tradition in Western Europe, Colchester 2010, s. 122-130. Na temat państwa prawnego w myśli von Mohla zob. M. Zmierczak, Ksztaltowanie się koncepcji państwa prawnego (na przykładzie niemieckiej myśli polityczno-prawnej), [w:] Demokratyczne państwo prawne, red. H. Rot, Wrocław 1992, s. 43-44; J. Hähnle, Die politischen Ideen Robert von Mohls. Ein Beitrag zur Geschichte des älteren süddeutschen Liberalismus, Tübingen 1921, s. 15-16; Der europäische Rechtsstaat 200 Zeugnisse seiner Geschichte, Hrsg. J. Brand, H. Hattenhauer, Heidelberg 1994, s. 97-98.

48 Von Mohl używał nawet określenia ,państwo prawne nowożytności” (Rechtsstaat der Neuzeit). Zob. R. von Mohl, Die Polizeiwissenschaft nach den Grundsätzen des Rechtsstaates, Erster Band, Tübingen 1866, s. 4. Welcker uważał, iż państwo prawne wyrasta poprzez przejście przez dwie formy stojące na niższym poziomie rozwoju: despocję i teokrację. Więcej o państwie prawnym w myśli tego uczonego zob. C.T. Welcker, Die letzten Gründe von Recht, Staat und Strafe philosophisch und nach den Gesetzen der merkwürdigsten Völker rechtshistorisch entwickelt, Giessen 1813, s. 71; Z.A. Maciąg, op. cit., s. 80-81.

49 R. von Mohl, Encyklopädie..., s. 326. 
dzy legalnej u Webera). Słusznie wnioskuje więc Michael Henkel, wskazując, iż Rechtsstaat u von Mohla jawi się jako wyraz historycznego wzrostu samoświadomości i mentalności określonego narodu ${ }^{50}$.

Kolejnym dowodem na poparcie głównej tezy niniejszego artykułu są wątpliwości von Mohla odnoszące się do samej nazwy: Rechtsstaat. Niemiecki liberał uważał ją za nie do końca udaną; podkreślał, że stosowanie pojęcia „państwo prawne” implikuje postrzeganie go jako organizmu, któremu przyświeca jedynie „cel prawny” (Rechtszweck rozumiany jako ochrona prawa poprzez wymiar sprawiedliwości). Taki obraz Rechtsstaat stał w sprzeczności z ideą, jaką w odniesieniu do tego typu państwa reprezentował von Mohl. Miał on bowiem pomijać drugą część działalności państwa prawnego, czyli działalność policyjną (polegającą na aktywnej trosce o dobrobyt ludności). Powyższe wątpliwości doprowadziły uczonego do rozważań, czy nie lepiej nazwać ten typ państwa „państwem prawno-policyjnym” (Recht-und-Polizei-Staat) czy też właśnie „państwem racjonalnym” (Verstandes-Staat $)^{51}$.

Opierając się na zasadach racjonalnego rozsądku, ludność organizująca się na zasadach państwa prawnego według von Mohla dochodzi do przekonania, iż jedynym doczesnym, wspólnym celem ludzi jest możliwie jak najpełniejsze wykształcenie i rozwijanie swych tzw. sił naturalnych (Naturkräfte) ${ }^{52}$. Istota ludzka, która weszła na odpowiednio wysoki (racjonalny) poziom rozwoju, nie może mieć innego celu życiowego swej ziemskiej egzystencji, jak ten wynikający z przekonania, iż jej zadaniem jest możliwie najpełniejsze i harmonijne wykształcenie zdolności oraz realizacja planów, a także zdobycie środków do ich osiągania ${ }^{53}$.

50 M. Henkel, Robert von Mohl, [w:] Politische Theorien des 19. Jahrhunderts Konservatismus, Liberalismus, Sozialismus, Hrsg. B. Heidenreich, Berlin 2002, s. 353.

51 R. von Mohl, Das Staatsrecht des Königreiches Württemberg, Erster Theil, s. 11; idem, Encyklopädie..., s. 326. Warto nadmienić, iż gatunek państwa prawnego może według von Mohla przybierać wiele różnorodnych form, które mogą się nawzajem przenikać. Rechtsstaat może być więc demokracją, i to w typie „czystym” (rządzą wszyscy uprawnieni bezpośrednio) oraz reprezentacyjnym (lud rządzi poprzez swych przedstawicieli, jak np. było według von Mohla w Anglii). Państwo prawne może objawić się też jako arystokracja oraz monarchia. Uczony wyróżnił monarchię absolutną i ograniczoną (albo przez „stany feudalne”, albo przez przedstawicieli ludu). Rechtsstaat może być poza tym tzw. państwem związkowym (Bundesstaat). W ramach państwa prawnego von Mohl wyróżnił jeszcze „państwo z podzielonymi władzami” (Der Staat mit getrennten Gewalten), opierające się na trójpodziale władz (władza ustawodawcza, wykonawcza i sądownicza). Co ciekawe, jego zdaniem taka forma nie odpowiada „realnemu życiu”, gdyż brakuje jej logiki i „mądrości politycznej”. Zob. idem, Das Staatsrecht des Königreiches Württemberg, Erster Theil, s. 15-21. Więcej o ocenie przez von Mohla teorii podziału władz (m.in. u Monteskiusza) zob. idem, Die Geschichte und Literatur der Staatswissenschaften..., s. 271-281. Na temat rodzajów państwa prawnego zob. idem, Encyklopädie..., s. 107.

52 Idem, Das Staatsrecht des Königreiches Württemberg, Erster Theil, s. 8. Podobnie: idem, Polizei, [w:] Staats-Lexikon oder Encyklopädie der Staatswissenschaften, Hrsg. C. von Rotteck, C. Welcker, 12 Bd., Altona 1841, s. 644.

53 Idem, Die Polizeiwissenschaft nach den Grundsätzen des Rechtsstaates, Erster Band, Tübingen 1832, s. 6 . 
Mówiąc o pozycji państwa prawnego w tym procesie, von Mohl stwierdza, iż jego rolą jest „takie uporządkowanie zbiorowego życia narodu, aby każdy jego członek był chroniony i wspierany w możliwie najswobodniejszym i najbardziej wszechstronnym ćwiczeniu i używaniu swych wszystkich sił"54. Widać więc wyraźnie, iż państwo prawne ma w jego ujęciu dwa zadania: po pierwsze, będzie to „uporządkowanie”, czyli utrzymywanie porządku (przede wszystkim porządku prawnego), a po drugie - wspieranie obywateli w realizacji ich dążeńt ${ }^{55}$.

Wobec tego za pierwszą zasadę w państwie prawnym, jak podnosi von Mohl, należy przyjąć „świętość wszelkiego prawa" ${ }^{56}$. Zadaniem Mohlowskiego Rechtsstaat jest zatem utrzymywanie i ochrona porządku prawnego jako podstawy wszelkiego dalszego działania oraz zapobieganie nieprawnym działaniom określonych jednostek ${ }^{57}$. Jednak myli się ten, kto wyciągnie wniosek, iż dla von Mohla (podobnie jak dla Kanta) ${ }^{58}$ ochrona prawa ma być jedynym zadaniem państwa. Jak wspomniano wyżej, Rechtsstaat w wydaniu liberalnego Niemca nie może być wyłącznie państwem wspomnianego „celu prawnego" 59 . Takie państwo uczony uznaje za niepełne oraz zadaje pytanie retoryczne: „Kto chciałby i mógłby żyć w takim państwie, które działa tylko jako wymiar sprawiedliwości, a nie dozwala żadnej pomocy policyjnej?" ${ }^{60}$.

${ }^{54}$ Ibidem, s. 7. Warto podkreślić, że von Mohl uważał, iż powstała w 1871 r. Rzesza Niemiecka była „szkolnym” przykładem Rechtsstaat w jego rozumieniu (idem, Deutsche Reichsstaatsrecht Rechtliche und politische Eröterungen, Tübingen 1873, s. 39). Rzeczywiście w preambule do Konstytucji Rzeszy Niemieckiej (Verfassung des deutschen Reichs) z 16 kwietnia 1871 r. czytamy, iż została ona utworzona w celu „ochrony obszaru Związku i obowiązującego na nim prawa, jak również w celu troski o dobrobyt Narodu Niemieckiego" - Verfassung des Deutschen Reichs (Gegeben Berlin, den 16. April 1871), Hrsg. L. von Rönne, Berlin-Leipzig 1882, s. 16. Więcej o ustroju i polityce Rzeszy Niemieckiej w epoce wilhelmińskiej zob. J. Kostrubiec, Nauka o państwie w myśli Georga Jellinka, Lublin 2015, s. 20-23.

55 Por. E. Angermann, op. cit., s. 121-122.

56 R. von. Mohl, Die Polizeiwissenschaft nach den Grundsätzen des Rechtsstaates, Erster Band, Zweite Auflage, s. 21.

57 Idem, Die Polizeiwissenschaft nach den Grundsätzen des Rechtsstaates, Erster Band, Tübingen 1866, s. 5 .

58 Więcej o koncepcji państwa prawa w myśli Kanta zob. K. Jońca, Ewolucja pojęcia „państwa prawnego” w niemieckiej doktrynie prawnej, „Przegląd Prawa i Administracji” 1976, t. 7, s. 215.

59 R. von Mohl, Das Staatsrecht des Königreiches Württemberg, Erster Theil, s. 11. Por. A. Dziadzio, Koncepcja państwa prawa w XIX wieku - idea i rzeczywistość, „Czasopismo Prawno-Historyczne" 2005, t. 57, z. 1, s. 181. Więcej o różnicach w nauce von Mohla i Kanta o państwie prawnym zob. I. Maus, Entwicklung und Funktionswandel der Theorie des bürgerlichen Rechtsstaats, [w:] Der bürgerliche Rechtsstaat, Hrsg. M. Tohipidur, Frankfurt am Main 1978, s. 18-19.

60 R. von Mohl, Die Polizeiwissenschaft nach den Grundsätzen des Rechtsstaates, Erster Band, Tübingen 1832, s. 9. Von Mohl stoi w opozycji nie tylko do Kanta, ale także do Wilhelma von Humboldta, który również uważał, iż rola państwa prawnego powinna się ograniczać do zapewnienia bezpieczeństwa prawnego jednostki i systemu ustrojowego. Zob. Z.A. Maciąg, op. cit., s. 79. 
Podkreślić przy tym należy, iż państwo prawne w nauce von Mohla bazowało na wolności obywatelskiej jako na „najwyższej zasadzie” (oberste Grundsatz) ${ }^{61}$. Prawem i obowiązkiem obywatela w Mohlowskim państwie prawnym jest działanie samodzielne, poruszanie się w granicach rozsądku i prawa w rozwoju własnych zdolności osobistych oraz realizacji celów życiowych ${ }^{62}$. Tam więc, gdzie obywatel nie narusza praw osoby trzeciej oraz „podąża za racjonalnym celem”, powinien mieć on swobodę działania ${ }^{63}$. Zadaniem państwa prawnego jest strzeżenie wolności obywatela i gwarantowanie mu powyższej swobody.

\section{ZASADY RACJONALNEGO WSPIERANIA OBYWATELI}

Jak pokazuje doświadczenie, w życiu ludzi mogą się jednak pojawiać przeszkody, które utrudniają lub uniemożliwiają im realizację swych celów życiowych. Mogą to być, po pierwsze, złe zamiary innych jednostek, a po drugie przewaga tzw. przeszkód zewnętrznych, czyli różnego rodzaju występujących w rzeczywistości stanów uniemożliwiających jednostce osiąganie jej życiowych zamierzeń $^{64}$. W nauce von Mohla obydwa rodzaje przeszkód muszą być usuwane przez państwo, czy to poprzez jego Justiz (Wymiar sprawiedliwości) czy też poprzez Polizei (Policję) ${ }^{65}$.

Więcej o celu państwa w myśli von Humboldta zob. W. von Humboldt, Der Zweck des Staates, [w:] Der Deutsche Liberalismus Die Entwicklung einer politischen Idee von Immanuel Kant bis Thomas Mann, Hrsg. F. Federici, Zürich 1946, s. 17-27; M. Chmieliński, Wilhelma von Humboldta idee ograniczenia państwa, „Czasopismo Prawno-Historyczne” 2002, t. 54, z. 1, s. 337-363.

${ }_{61}$ R. von Mohl, Die Polizeiwissenschaft nach den Grundsätzen des Rechtsstaates, Erster Band, Zweite Auflage, s. 8.

62 K. Sobota, Das Prinzip Rechtsstaat, Tübingen 1997, s. 309.

63 R. von Mohl, Die Polizeiwissenschaft nach den Grundsätzen des Rechtsstaates, Erster Band, Tübingen 1832, s. 14.

${ }^{64}$ Idem, Die Polizeiwissenschaft nach den Grundsätzen des Rechtsstaates, Erster Band, Zweite Auflage, s. 9-10.

${ }^{65}$ Idem, Das Staatsrecht des Königreiches Württemberg, Erster Theil, s. 8. Policja była rozumiana przez von Mohla jako uosobienie wszelkich różnorodnych instytucji państwa, których celem było oddalanie zewnętrznych przeszkód stojących na drodze do wszechstronnego, dozwolonego rozwoju sił ludzkich, których jednostka nie jest w stanie sama pokonać (zob. idem, Polizei, s. 646). Henkel (op. cit., s. 348) pod dziewiętnastowiecznym pojęciem policji rozumie całość praktycznej administracji państwa, zorientowanej na osiągnięcie celu państwa, jakim był dobrobyt obywateli. Więcej o nauce o policji u von Mohla zob. H. Maier, Die ältere deutsche Staats- und Verwaltungslehre (Polizeiwissenschaft), Neuwied am Rhen-Berlin 1966, s. 262-278. Na temat pojęcia „policja” zob. W. Szwarc, Zarys ewolucji pojęcia ,policji” w monarchii pruskiej w XVIII i XIX w., [w:] Wybrane problemy teorii i praktyki państwa i prawa, red. H. Groszyk, L. Dubel, Lublin 1986, s. 117-133; D. Janicka, Ustrój administracji w nowożytnej Europie. Zarys wyktadu, Torun 2002, s. 44; K. Dąbrowski, Ewolucja pojęcia policji w kontekśsie genezy żandarmerii w Niemczech, „Studia Iuridica Lublinensia" 2016, nr 3, DOI: http://dx.doi.org/10.17951/sil.2016.25.3.205, s. 205-208. O rozwoju nauki o policji w Niemczech por. J. Malec, D. Malec, Historia administracji i myśli ad- 
Wymiar sprawiedliwości odpowiadał w nauce von Mohla za ochronę porządku prawnego w państwie prawnym ${ }^{66}$. Racjonalność Mohlowskiego Rechtsstaat objawia się jednak z całą mocą przy analizie zasad aktywności policyjno-administracyjnej w państwie. Działalność policyjna była częścią ogólnej działalności administracyjnej w Mohlowskim państwie prawnym ${ }^{67}$, którą Danuta Janicka przyrównuje do administracji wewnętrznej ${ }^{68}$. Administracja (opisywana jako Verwaltung, czyli 'zarządzanie, zarząd' $)^{69}$ była rozumiana przez niemieckiego uczonego jako urzeczywistnianie zasad przyjętych w ustroju państwa (Verfassung) oraz wypełnianie jego celów w pojedynczych przypadkach ${ }^{70}$. Należy nadmienić, iż Verfassung (wyraz ten można przetłumaczyć jako 'urządzenie, układ, organizacja ${ }^{71}$, a w dzisiejszym rozumieniu również 'ustrój, konstytucja') według uczonego określa, do jakiego rodzaju i do jakiej formy ustrojowej należy państwo oraz jakie wobec tego cele i zadania powinno wypełniać 72 .

Kształt administracji państwa będzie wyglądać inaczej w zależności od tego, z jakim jego gatunkiem mamy do czynienia. O ile w państwie despotycznym administracja będzie służyć tylko spełnieniu potrzeb władcy, o tyle w państwie

ministracyjnej, Kraków 2000, s. 54-59; M. Stolleis, Geschichte des öffentlichen Rechts in Deutschland, Bd. 1: Reichspublizistik und Poliecywissenschaft, München 1988, s. 366-371.

${ }_{66}$ Więcej o podziale między Justiz i Polizei u von Mohla zob. B. Stöcker, Die Gemeinwohltheorie Robert von Mohls ale ein früher Ansatz des sozialen Rechtsstaatsprinzips, München 1992, s. 38.

${ }_{67}$ Warto podkreślić, iż Bosiacki ,naukę policji” utożsamia właśnie z dzisiejszą ,administracją". Zob. A. Bosiacki, Robert von Mohl i poczattki koncepcji państwa prawnego, [w:] Idee jako źródto instytucji politycznych i prawnych, red. L. Dubel, Lublin 2003, s. 320. Podobnie: B. Stöcker, op. cit., s. 38. O pojęciu administracji por. G. Smyk, Poczattki ewolucji podstawowych pojęć i definicji w europejskiej nauce administracji, „Studia z Dziejów Państwa i Prawa Polskiego” 2014, t. 42, s. $109-114$.

68 D. Janicka, op. cit., s. 45.

${ }^{69}$ Niemiecko-polski słownik wyrazów prawniczych i administracyjnych, Kraków 1874, s. 318.

70 R. von Mohl, Das Staatsrecht des Königreiches Württemberg, Zweiter Theil: Das Verwaltungsrecht, Tübingen 1831, s. 4. Podobnie: idem, Encyklopädie..., s. 136. Więcej o problemie administracji publicznej: H. Izdebski, Badania nad administracja publiczna, [w:] Administracja ..., s. 13-26.

${ }_{71}$ Niemiecko-polski stownik..., s. 305.

72 R. von Mohl, Das Staatsrecht des Königreiches Württemberg, Zweiter Theil, s. 3. Von Mohl uważał, iż każde państwo posiada swój Verfassung, czyli zasady odnoszące się do jego kształtu i działalności, które mogą przybrać różną formę (np. spisanej konstytucji). Podobnie Verfassung rozumiał inny niemiecki liberał - Friedrich Christoph Dahlmann, który wskazywał, iż są to zasady regulujące „uporządkowany stan wspólnoty politycznej”. Więcej: F.Ch. Dahlmann, Ein Wort über Verfassung, [w:] Der Deutsche Liberalismus..., s. 113-117; W. Bleek, Friedrich Christoph Dahlmann und die „gute “ Verfassung, „Politische Vierteljahresschrift“ 2007, Nr. 1, s. 32. Warto dodać, iż Michael Stolleis uznaje von Mohla za tego uczonego, który jako jeden z pierwszych dokonał podziału na prawo ustrojowe (konstytucyjne, Verfassungsrecht) i prawo administracyjne (Verwaltungsrecht). Zob. M. Stolleis, Geschichte des öffentlichen Rechts in Deutschland, Bd. 2: Staatsrechtslehre und Verwaltungswissenschaft 1800-1914, München 1992, s. 173. Na temat podziału na prawo konstytucyjne i administracyjne u von Mohla zob. P. Badura, Das Verwaltungsrecht des liberalen Rechtsstaates, Göttingen 1967, s. 22-23. 
prawnym będzie służyć zwierzchności politycznej (władzy), ale i narodowi. W despotii postępowanie administracji będą cechować szybkość, ostrość i nieubłagalność. W Rechtsstaat, w którym obywatel może wejść w konflikt nie tylko z innym obywatelem, ale i z całym państwem, administrację będzie charakteryzować oparcie się na logicznych dowodach oraz powtarzalnych decyzjach ${ }^{73}$.

Najważniejszą zasadą aktywności policyjnej państwa prawnego jest działanie wtedy, gdy tzw. siły prywatne obywateli (Privatkräfte der Staatsbürger) nie są w stanie same uporać się z wypełnieniem racjonalnych, dozwolonych prawnie i wartościowych dla ogółu inicjatyw ${ }^{74}$. O racjonalności świadczy to, że państwo ma tylko wspierać, a nie w pełni przejmować zadania polegające na wypełnianiu celów życiowych ${ }^{75}$. Charakteryzuje je więc subsydiarność ${ }^{76}$, kluczowa chociażby dla właściwego rozumienia tzw. społecznego państwa prawnego również dzisiaj. Państwo prawne i jego administracja nie powinny ingerować (zwalczać przeszkód) tam, gdzie mogą zostać pokonane przy użyciu własnych sił obywatela lub - co bardzo ważne - różnego rodzaju stowarzyszeń prywatnych ${ }^{77}$. Jest to zasada podstawowa wspierającej aktywności państwa, której celem jest w istocie ochrona wolności jednostki. Jeżeli bowiem obywatel państwa jest w stanie poradzić sobie sam z jakąkolwiek przeszkodą w spełnianiu celów życiowych, a państwo mimo wszystko wyręcza go w tym, to będzie ono niszczyć jego wolność - zamiast subsydiarnego wsparcia pojawi się ograniczanie ${ }^{78}$. Stanowczo podkreśla von Mohl, iż takie działanie państwa byłoby pogwałceniem najwyższej zasady państwa prawnego, jaką jest przecież wolność obywateli ${ }^{79}$.

Warto wspomnieć, iż uczonemu nie chodziło o to, aby państwo spełniało wszelkie różnorodne cele poszczególnych jednostek. Kluczem do zrozumienia tej instytucji jest teza, iż państwo prawne ma wspierać „,zbiorowy pogląd na życie” (Gesamt-Lebensansicht) określonego narodu (omówiony dalej) ${ }^{80}$. Niezmiernie ważną zasadą działania państwa prawnego jest nadanie przez von Mohla prymatu tzw. dobru powszechnemu (Gemeinwohl) ${ }^{81}$. Dobro wspólnoty jest uznawane

73 R. von Mohl, Das Staatsrecht des Königreiches Württemberg, Zweiter Theil, s. 5-6.

74 Idem, Die Polizeiwissenschaft nach den Grundsätzen des Rechtsstaates, Erster Band, Tübingen 1832, s. 21. Więcej o zasadach działania policji: Z.A. Maciąg, op. cit., s. 92.

75 R. von Mohl, Encyklopädie..., s. 77.

76 M. Henkel, op. cit., s. 354. O subsydiarnym działaniu administracji w myśli von Mohla zob. B. Stöcker, op. cit., s. 43-48.

77 R. von. Mohl, Die Polizeiwissenschaft nach den Grundsätzen des Rechtsstaates, Erster Band, Tübingen 1866, s. 20.

78 Ibidem.

79 Idem, Die Polizeiwissenschaft nach den Grundsätzen des Rechtsstaates, Erster Band, Zweite Auflage, s. 17.

80 Ibidem, s. 7.

81 Więcej: idem, Die Polizeiwissenschaft nach den Grundsätzen des Rechtsstaates, Erster Band, Tübingen 1866, s. 35. 
za ważniejsze od dobra jednostki czy wąskiej grupy. Zawsze, gdy dochodzi do niezgodności między interesami jednostki czy małej liczby jednostek a interesem dobra wspólnego, pierwszeństwo ma wspólnota ${ }^{82}$. Pomoc państwa nie może być realizowana według osobistych życzeń poszczególnych obywateli, lecz na podstawie kryteriów obiektywnych określonego przypadku ${ }^{83}$. Od państwa nie można też żądać działania wtedy, gdy np. w określonych częściach kraju panują różne warunki determinujące wypełnianie różnych zadañ ${ }^{84}$.

Kolejnym potwierdzeniem tezy o racjonalności państwa u von Mohla jest stwierdzenie, iż państwo ma wkraczać tylko przy „rozsądnych zamiarach” (vernunftgemäßen Absichten) swych obywateli, odrzucając wsparcie celów nieracjonalnych ${ }^{85}$. Skoro zadaniem państwa prawnego jest zwalczanie przeszkód zewnętrznych, to według von Mohla byłoby nierozsądne ze strony państwa wspieranie niecelowych i nieracjonalnych działań, które zostały spowodowane przez określoną jednostkę ${ }^{86}$. Obywatel nigdy nie może również realizować swoich celów, choćby były one racjonalne i dozwolone przez prawo, poprzez pogorszenie sytuacji osoby trzeciej ${ }^{87}$.

Wreszcie racjonalne wsparcie państwa nie może polegać na wspieraniu realizacji wszystkich pojedynczych celów jednostek, lecz tylko celów uznawanych za powszechnie wymagalne ${ }^{88}$. Powód jest prozaiczny - otóż państwo nie może być w stanie wesprzeć zamiarów każdego pojedynczego obywatela nawet wtedy, gdyby były one i racjonalne, i zgodne z prawem. Ogólna siła państwa może być więc wykorzystywana tylko do realizacji ogólnych celów ${ }^{89}$. Dobrym przykładem „ogólnej” działalności administracji państwowej jest działalność medyczna. Według von Mohla zadaniem państwa nie jest troska o zdrowie każdego indywidualnego obywatela, lecz zapewnienie ogólnych środków zaradczych sprzyjających zdrowiu wszystkich jego mieszkańców ${ }^{90}$.

${ }^{82}$ Idem, Die Polizeiwissenschaft nach den Grundsätzen des Rechtsstaates, Erster Band, Zweite Auflage, s. 26.

83 Ibidem, s. 27.

84 Ibidem, s. 23.

85 Idem, Die Polizeiwissenschaft nach den Grundsätzen des Rechtsstaates, Erster Band, Tübingen 1832, s. 18. Dla von Mohla przykładem takiego nieracjonalnego działania byłoby wspieranie przez państwo utworzenia katedr kabały czy astrologii na uniwersytetach. Ibidem, s. 19.

${ }^{86}$ Idem, Die Polizeiwissenschaft nach den Grundsätzen des Rechtsstaates, Erster Band, Zweite Auflage, s. 26.

87 Ibidem.

88 Idem, Encyklopädie..., s. 282.

89 Idem, Die Polizeiwissenschaft nach den Grundsätzen des Rechtsstaates, Erster Band, Zweite Auflage, s. 22.

90 Idem, Die Polizeiwissenschaft nach den Grundsätzen des Rechtsstaates, Erster Band, Tübingen 1866, s. 13. 


\section{PODSUMOWANIE}

Reasumując, należy stwierdzić, iż niniejsze rozważania dowodzą tezy o racjonalności pojmowania państwa prawnego w myśli von Mohla, które Katharina Sobota nazwała nawet ,porządkiem rozumu"91. Racjonalność, rozsądek, niemiecki Vernunft są kluczem do rozumienia tej idei. Jest to idea państwa opartego na prawie, lecz także działającego w sposób subsydiarny tam, gdzie jest to potrzebne, za pomocą swego aparatu administracyjno-biurokratycznego. Przed Weberem żaden z niemieckich uczonych nie analizował zjawiska biurokracji administracyjnej tak, jak von Mohl. Starał się on widzieć w administracji i jej biurokracji nie „wynaturzone zjawisko”, lecz nieunikniony fenomen nowoczesnego państwa prawnego. Ponadto chciał, aby działała ona w sposób racjonalny ${ }^{92}$. Dlatego u von Mohla pojawia się nie tylko oparcie na prawie jako podstawie wszelkiego działania, ale również subsydiarność w pomocy obywatelom jako gwarancja ich wolności i efektywności państwa ${ }^{93}$.

\section{BIBLIOGRAFIA}

Angermann E., Robert von Mohl 1799-1875. Leben und Werk eines altliberalen Staatsgelehrten, Neuwied 1962.

Augustyniak M., Max Weber o władzy i odpowiedzialności w polityce, „Studia Prawnoustrojowe” 2010, nr 11.

Badura P., Das Verwaltungsrecht des liberalen Rechtsstaates, Göttingen 1967.

Beetham D., Max Weber and the Theory of Modern Politics, Cambridge 1985.

Beyme K. von, Einleitung, [w:] R. von Mohl, Politische Schriften, Köln-Opladen 1966.

Beyme K. von, Geschichte der politischen Theorien in Deutschland 1300-2000, Wiesbaden 2009.

Blackburn S., Oksfordzki stownik filozoficzny, Warszawa 2004.

Blau P.M., Critical Remarks on Weber's Theory of Authority, "The American Political Science Review" 1963, Vol. 57(2).

Bleek W., Friedrich Christoph Dahlmann und die ,gute“ Verfassung, „Politische Vierteljahresschrift" 2007, Nr. 1.

Bleek W., Geschichte der Politikwissenschaft in Deutschland, München 2001.

Bosiacki A., Egalitaryzm a elitaryzm w klasycznej koncepcji państwa prawnego w Niemczech XIX wieku, [w:] Księga życia i twórczości. Księga Pamiatkowa dedykowana Profesorowi Romanowi A. Tokarczykowi, t. 5: Prawo, red. Z. Władek, J. Stelmasiak, W. Gogłoza, K. Kukuryk, Lublin 2013.

Bosiacki A., Robert von Mohl i początki koncepcji państwa prawnego, [w:] Idee jako źródło instytucji politycznych i prawnych, red. L. Dubel, Lublin 2003.

Bosiacki A., Wstęp, [w:] R. von Mohl, Encyklopedia umiejętności politycznych, Warszawa 2003.

Breuer S., Rationale Herrschaft. Zu einer Kategorie Max Webers, „Politische Vierteljahrschrift“ 1990, Bd. 31, Nr. 1.

${ }^{91}$ K. Sobota, op. cit., s. 308.

92 K. von Beyme, Einleitung, [w:] R. von Mohl, Politische Schriften, Köln-Opladen 1966, s. XVI.

93 Słusznie więc Wilhelm Bleek uznał von Mohla za jednego z ,duchowych ojców” koncepcji socjalnego państwa prawnego (sozialer Rechtsstaat) w Niemczech. Zob. W. Bleek, Geschichte der Politikwissenschaft in Deutschland, München 2001, s. 21. 
Burska-Cieślak J., Geneza pojęcia socjalnego państwa prawnego w doktrynie niemieckiej, [w:] Państwo - ustrój-konstytucja. Studia, red. L. Antonowicz, Lublin 1991.

Chmieliński M., Wilhelma von Humboldta idee ograniczenia państwa, „Czasopismo Prawno-Historyczne" 2002, t. 54, z. 1.

Constas H., Max Weber's Two Conceptions of Bureaucracy, “American Journal of Sociology” 1958, Vol. 63(4).

Dahlmann F.Ch., Ein Wort über Verfassung, [w:] Der Deutsche Liberalismus Die Entwicklung einer politischen Idee von Immanuel Kant bis Thomas Mann, Hrsg. F. Federici, Zürich 1946.

Dąbrowski K., Ewolucja pojęcia policji w kontekście genezy żandarmerii w Niemczech, „Studia Iuridica Lublinensia" 2016, nr 3, DOI: http://dx.doi.org/10.17951/sil.2016.25.3.205.

Der europäische Rechtsstaat 200 Zeugnisse seiner Geschichte, Hrsg. J. Brand, H. Hattenhauer, Heidelberg 1994.

Drozdowicz Z., O racjonalności w religii i w religijności (raz jeszcze), Poznań 2010.

Dubel L., Robert von Mohl, [w:] idem, Historia doktryn politycznych i prawnych do schytku XX wieku, Warszawa 2012.

Dyson K.H.F., The State Tradition in Western Europe, Colchester 2010.

Dziadzio A., Koncepcja państwa prawa w XIX wieku - idea i rzeczywistość, „Czasopismo Prawno-Historyczne" 2005, t. 57, z. 1.

Haller C.L. von, Restauration der Staatswissenschaft oder Theorie des natürlich-geselligen Zustands, der Chimäre des künstlich-bürgerlichen entgegengesetzt, $1 \mathrm{Bd}$., Winterthur 1820.

Hähnle J., Die politischen Ideen Robert von Mohls. Ein Beitrag zur Geschichte des älteren süddeutschen Liberalismus, Tübingen 1921.

Henkel M., Robert von Mohl, [w:] Politische Theorien des 19. Jahrhunderts Konservatismus, Liberalismus, Sozialismus, Hrsg. B. Heidenreich, Berlin 2002.

Hilbert R.A., Bureaucracy as Belief, Rationalization as Repair: Max Weber in a Post-Functionalist Age, "Sociological Theory" 1987, Vol. 5(1).

Humboldt W. von, Der Zweck des Staates, [w:] Der Deutsche Liberalismus Die Entwicklung einer politischen Idee von Immanuel Kant bis Thomas Mann, Hrsg. F. Federici, Zürich 1946.

Izdebski H., Badania nad administracja publiczna, [w:] Administracja publiczna, red. J. Hausner, Warszawa 2003.

Janicka D., Ustrój administracji w nowożytnej Europie. Zarys wykładu, Toruń 2002.

Jońca K., Ewolucja pojęcia „państwa prawnego” w niemieckiej doktrynie prawnej, „Przegląd Prawa i Administracji” 1976, t. 7.

Kopaliński W., Słownik wyrazów obcych i obcojęzycznych z almanachem, Warszawa 2007.

Kostrubiec J., Nauka o państwie w myśli Georga Jellinka, Lublin 2015.

Levine D.N., Rationality and Freedom: Weber and Beyond, "Sociological Inquiry" 1981, Vol. 51(1).

Łuszczyńska M., Ubi ratio, ibi ius. Doktryna prawna Świętego Tomasza z Akwinu, Lublin 2013.

Maciąg Z.A., Ksztaltowanie zasad państwa demokratycznego, prawnego i socjalnego w Niemczech (do 1949 r.), Białystok 1998.

Maier H., Die ältere deutsche Staats- und Verwaltungslehre (Polizeiwissenschaft), Neuwied am Rhen-Berlin 1966.

Malec J., Malec D., Historia administracji i myśli administracyjnej, Kraków 2000.

Maus I., Entwicklung und Funktionswandel der Theorie des bürgerlichen Rechtsstaats, [w:] Der bürgerliche Rechtsstaat, Hrsg. M. Tohipidur, Frankfurt am Main 1978.

Mazur S., Historia administracji publicznej, [w:] Administracja publiczna, red. J. Hausner, Warszawa 2003.

Mohl R. von, Das Staatsrecht des Königreiches Württemberg, Erster Theil, Tübingen 1829.

Mohl R. von, Das Staatsrecht des Königreiches Württemberg, Zweiter Theil: Das Verwaltungsrecht, Tübingen 1831.

Mohl R. von, Deutsche Reichsstaatsrecht Rechtliche und politische Eröterungen, Tübingen 1873. 
Mohl R. von, Die Geschichte und Literatur der Staatswissenschaften in Monographieen dargestellt, Erster Band, Erlangen 1855.

Mohl R. von, Die Polizeiwissenschaft nach den Grundsätzen des Rechtsstaates, Erster Band, Tübingen 1832 .

Mohl R. von, Die Polizeiwissenschaft nach den Grundsätzen des Rechtsstaates, Erster Band, Zweite Auflage, Tübingen 1844.

Mohl R. von, Die Polizeiwissenschaft nach den Grundsätzen des Rechtsstaates, Erster Band, Tübingen 1866.

Mohl R. von, Encyklopädie der Staatswissenschaften, Zweite Auflage, Tübingen 1872.

Mohl R. von, Encyklopedia umiejętności politycznych, wstęp A. Bosiacki, Warszawa 2003.

Mohl R. von, Polizei, [w:] Staats-Lexikon oder Encyklopädie der Staatswissenschaften, Hrsg. C. von Rotteck, C. Welcker, 12 Bd., Altona 1841.

Niemiecko-polski słownik wyrazów prawniczych i administracyjnych, Kraków 1874.

Nowacki J., Państwo prawne w typologii państw Roberta von Mohla, [w:] Przybliżanie przeszłości. Księga pamiątkowa ofiarowana Profesorowi Czesławowi Głombikowi z okazji czterdziestolecia pracy nauczycielskiej, red. J. Bańka, Katowice 1998.

Polaczuk P., O racjonalności działania w ujęciu Maksa Webera, „Studia Warmińskie” 2011, t. 48.

Raiser T., Max Weber und die Rationalität des Rechts, „Juristen Zeitung“ 2008, Nr. 18.

Schmitz H., Die Staatsauffassung Robert von Mohls unter Berücksichtigung der verfassungs-geschichtlichen Entwicklung und des positivistischen Staatsdenkens, Köln 1965.

Smyk G., Początki ewolucji podstawowych pojęć i definicji w europejskiej nauce administracji, „Studia z Dziejów Państwa i Prawa Polskiego” 2014, t. 42.

Sobolewska B., Sobolewski M., Myśl polityczna XIX i XX wieku. Liberalizm, Warszawa 1978.

Sobota K., Das Prinzip Rechtsstaat, Tübingen 1997.

Stolleis M., Geschichte des öffentlichen Rechts in Deutschland, Bd. 1: Reichspublizistik und Poliecywissenschaft, München 1988.

Stolleis M., Geschichte des öffentlichen Rechts in Deutschland, Bd. 2: Staatsrechtslehre und Verwaltungswissenschaft 1800-1914, München 1992.

Stöcker B., Die Gemeinwohltheorie Robert von Mohls ale ein früher Ansatz des sozialen Rechtsstaatsprinzips, München 1992.

Swidler A., The Concept of Rationality in the Work of Max Weber, "Sociological Inquiry" 1973, Vol. 43(1).

Szwarc W., Zarys ewolucji pojęcia ,policji” w monarchii pruskiej w XVIII i XIX w., [w:] Wybrane problemy teorii i praktyki państwa i prawa, red. H. Groszyk, L. Dubel, Lublin 1986.

Verfassung des Deutschen Reichs (Gegeben Berlin, den 16. April 1871), Hrsg. L. von Rönne, Berlin-Leipzig 1882.

Weber M., Gospodarka i spoteczeństwo. Zarys socjologii rozumiejacej, Warszawa 2002.

Welcker C.T., Die letzten Gründe von Recht, Staat und Strafe philosophisch und nach den Gesetzen der merkwürdigsten Völker rechtshistorisch entwickelt, Giessen 1813.

Wielecki K., Władza i podmiotowość, „Zeszyty Naukowe Wyższej Szkoły Bankowej w Poznaniu” 2013, $\mathrm{nr} 4$.

Zmierczak M., Kształtowanie się koncepcji państwa prawnego (na przykładzie niemieckiej myśli polityczno-prawnej), [w:] Demokratyczne państwo prawne, red. H. Rot, Wrocław 1992. 


\section{SUMMARY}

The idea of the state of law (Rechtsstaat) derives from the sphere of German science. Its sources can be found at the turn of the $18^{\text {th }}$ century, in the works of scholars like Immanuel Kant or Johann Wilhelm Petersen (publishing under pseudonym Johann Wilhelm Placidus). This article refers to the origins of the legal state idea in German thought. The major task was to analyze the early conception of Rechtsstaat idea in the thought of Robert von Mohl, German, early-liberal scholar, and politician. The article shall prove that the state of law concept in von Mohl's thought was the rational one. This rationality was expressed not only by the "holiness of law" rule but also by assigning the state of law to fulfill the special task. This task was to support the citizens in overcoming obstacles that may occur in the realization of their "life goals". The rationality of this concept proves the fact that this support should have a subsidiary nature. State should act only in the last resort when the forces and abilities of individuals and their free associations are insifficient.

Keywords: Robert von Mohl; state of law; Rechtsstaat; rationality; subsidiarity

\section{STRESZCZENIE}

Idea państwa prawnego (Rechtsstaat) wywodzi się z kręgu nauki niemieckiej. Jej źródła sięgają do przełomu XVIII i XIX w. i do twórczości takich uczonych, jak Immanuel Kant czy Johann Wilhelm Petersen (tworzący pod pseudonimem Johann Wilhelm Placidus). Niniejszy artykuł odnosi się do początków idei państwa prawnego w myśli niemieckiej i jest próbą analizy postrzegania idei Rechtsstaat $\mathrm{w}$ myśli profesora i polityka niemieckiego wczesnego liberalizmu - Roberta von Mohla. Głównym celem było wykazanie, iż państwo prawne w jego rozumieniu było państwem racjonalnym. Racjonalność ta miała się wyrażać nie tylko w oparciu państwa prawnego na zasadzie ,świętości prawa”, ale również na nadaniu mu zadania specjalnego rodzaju. Było nim wspieranie obywateli w pokonywaniu przeszkód stojących im na drodze w realizacji tzw. celów życiowych. O racjonalności tego konceptu świadczy fakt, iż państwo miało pomagać obywatelom w sposób subsydiarny. Powinno ono w ostateczności działać wtedy, gdy nie starcza sił obywatelom lub ich organizacjom.

Słowa kluczowe: Robert von Mohl; państwo prawne; Rechtsstaat; racjonalność; subsydiarność 